\title{
Embodying the Anthropocene: Embattled crustaceans, extractivism, and eco-tourism on Christmas Island (Indian Ocean)
}

(In memoriam Alison Rahn, 1962-202I)

\author{
Philip Hayward \\ University of Technology Sydney, Australia \\ LabX, Southern Cross University, Lismore, Australia \\ prhshima@gmail.com
}

\begin{abstract}
Christmas Island, in the north-eastern Indian Ocean, remained uninhabited until 1888 when British entrepreneurs established a phosphate mining operation that has continued to the present. Over the last 132 years, the island has experienced a series of impacts that typify the effects of extractivism globally. Acquired by Australia in 1958, the island has also been the site of a major immigration detention centre, set up in 2006 to process and deter Asian asylum seekers. In recent decades, tourism has also been added to the economic mix in a form primarily orientated to the island's distinct fauna, an enterprise that co-exists uneasily with established mining and internment operations. In these regards, the island has rapidly experienced a range of transnational pressures that have distorted and compromised its environment. As such, the island's recent 'biography' exemplifies the impact and scale of integrated Anthropocene factors. Drawing on recent work on the nature of human ecodynamics, this article examines the character and role of the island's eco-assets - and its crustaceans, in particular - in the emerging experience economy of eco-tourism, illustrating the tensions and instability underlying the latter and its awkward co-existence with mining and detention operations. In this manner, the article characterises the Anthropocene as the central determinant of the present and of possible futures for the island.
\end{abstract}

Keywords: Anthropocene, Christmas Island, crustaceans, eco-tourism, extractivism, human ecodynamics

https://doi.org/10.24043/isj.145 • Received April 2020, accepted September 2020

(C) Island Studies Journal, 2021

\section{Introduction}

This article combines macro- and micro- perspectives on and analyses of Christmas Island (henceforth C.I.), located in the eastern Indian Ocean (10 25' South, $105^{\circ} 40^{\prime}$ East), with particular regard to its relatively brief (132 year) period of human settlement. The article examines the nature of extractivist activities on the island; the industrial and socio-economic organisation that has eventuated; attempts to develop tourism as an alternative to/replacement 
of extractivism; and recent geo-political events that the island has found itself situated within and impacted by. Drawing on Bennett (2010), and my own previous theorisation of aquapelagic assemblages (Hayward, 2012), I approach C.I. as an assemblage of animate and inanimate elements in which both have agency and thereby parallel Haraway's (2015, p. 9) more general inquiry about the contemporary planet:

What are the effects of bioculturally, biotechnically, biopolitically, historically situated people [...] relative to, and combined with, the effects of other species assemblages and other biotic/abiotic forces? No species, not even our own [...] acts alone; assemblages of organic species and of abiotic actors make history, the evolutionary kind and the other kinds too.

While the article does not address the intricacies of C.I.'s community, social concerns are included within the article's consideration of ecodynamics. Human ecodynamics has been defined as addressing "processes of stability, resilience, and change in socio-ecological relationships or systems" involving "interdisciplinary study of the human condition as it affects and is affected by the rest of the non-human world" (Fitzhugh et al., 2018, p. 1076)7. As defined by Fitzhugh and colleagues (2018, p. 1077, ecodynamics addresses past and present "coupled human-natural systems" in manners that suggest how we might best engage with the Anthropocene in order to produce more resilient and sustainable configurations. Retaining this focus, I also try to complement the formulation by addressing the condition of endogenous species as they are affected by the external world and principally by exogenous species such as humans and insects.

While much research in human ecodynamics has explored 'big picture' and/or historically protracted situations, I apply my nuanced ecodynamic perspective to a brief - but nonetheless dramatic - history of a small, colonised isolate. Following contextual analyses that draw on previously published sources in Sections I and II, Section III is informed by my fieldwork on C.I. and my attempts to reconcile different aspects of the ecodynamics of the island with regard to the plight of endogenous fauna. This approach derives from traditions in cultural anthropology that include personal experience of and reflections on sites as ways of gaining intellectual purchase on broad issues, James Clifford's Fort Ross Meditation (1997, pp. 299-347) being a particularly ambitious example. As Clifford (1997, p. 302) emphasises in that essay, the challenge for cultural anthropology (and, I would argue, island studies), is to recognise that economic, political, environmental, social, and cultural forces "are materialized as historical reality only through particular local projects and stories." As Clifford (1997, p. 302) asserts, the latter "are neither uniform nor finally determined" and historical reality is thereby "a changing set of determinations not a cumulative process or teleology." It is notable that Clifford's essay and its statement of challenges were made before the full impact of the Anthropocene began to emerge and are, arguably, even more apposite for current researchers. Subsequent sections of this article take their cue from Clifford by addressing a particular case study. In order to provide a central 'telling' example to illustrate the specificity - and specific complexity - of C.I.'s situation, I focus on the role and plight of the island's prolific crustaceans, relating the story of their recent experience of the Anthropocene through the present of C.I. This stated, my approach differs from Clifford's, which he significantly characterised as a meditation (in the manner of a reverie) occasioned by a visit to a (highly 
managed) Californian coastal heritage site. As the following discussions elaborate, I was primarily concerned with exploring the specifics of local fauna's interaction with industrial, carceral, and transport operations and technologies and the 'meanings' of the encounters between them. In order to observe and reflect on these, I engaged with the visceralities of variously imperilled, afflicted, or squashed crustaceans and I had close encounters with speeding trucks, security guards, and dockyard operations. Many of these interactions were unsettling and my unease in contemplating the island's nascent experience economy under these circumstances set the tone for this article, which I characterise, in its title, as being concerned with the "problematic" nature of its emerging tourism sector in the Anthropocene. Before proceeding, it is also necessary to comment on three further factors: my understanding of and engagement with the much-debated phenomenon of the Anthropocene, the basis of my perception and representations of crustaceans, and the purpose of my experiential storytelling in Section III.

As readers will be aware, the Anthropocene has been characterised as the period in which human activities have transformed the global environment and climate patterns, leading, most recently, to global warming and sea-level rise. While the suite of these activities and their impacts upon the planet have been widely - if not comprehensively - accepted, the term itself has been the subject of much debate. Several alternatives have been proposed, including ones based on socio-economic characterisations, such as the 'Capitalocene', or in reference to particular models of organisational exploitation, such as the 'Plantationocene'. Although largely overlooked, Rice (2017, p. 1) has also credibly suggested the 'Pleonexycene' (after pleonexy, a term referring to insatiable avarice) as an alternative term that has "clear advantages" over the term Anthropocene:

in that, civilizations have not chosen to damage and pollute but simply to overconsume. 'Pleonexycene' fits well in that it refers to an unprecedented epoch of unsustainable demands upon resources. The 'Early Pleonexycene' epoch begins with damage due to the commencement of agriculture and empires. The 'Late Pleonexycene' marks the 'great acceleration' of over-consumption catalysed by Western aggressive techno-industrial commerce (WATIC).

Rice's characterisation is particularly apposite with regard to the development of C.I.'s mining industry as a manifestation of "aggressive techno-industrial commerce" and of the island's community as primarily serving and servicing that industry. In this regard, I understand extractivism to exemplify the Anthropocene/Pleonexycene, both in general and in terms of its impact on C.I.

Approaching the epoch from a different perspective, Haraway (2016) has proposed the term 'Chthulucene' to describe the manner in which human and non-human species are closely associated in period of profound environmental turmoil. One of the core concepts in her idealistic and allusive vision is that of kinship and, specifically, of humans "making kin" (Haraway, 2016) with non-humans in order to halt the extinction narratives underway across the planet and to form the basis of a more holistic method of planetary co-habitation. And core to this, Haraway (2016) asserts, is recognising and staying with the "trouble" that afflicts us and actively seeking "environmental justice" in our inhabitation of the world and in our engagement with other species. While I use the term 'Anthropocene' throughout this essay, 
Haraway's perspective substantially informs my address to "the trouble" between humans and crustaceans and "trouble" with local eco-tourism that I outline in in Section III. Similarly, I acknowledge her related call (Haraway, 2018, p. 105) for "generative, effective multi-species environmental justice" to proceed through "storytelling" as a "thinking practice, not an embellishment [emphasis added] to thinking." I present my essay reflectively, aided by images, in order to tell stories about crustacean-human interactions on C.I. and to demonstrate how they embody wider processes. The account I give is also significant for relating the experiences of an island that lacks an indigenous population with long-established local traditions of subsistence, adaptability, and resilience. Put simply, there is nothing for C.I.'s population to 'fall back on' - no deep-seated cultural knowledge of the biological and material resources of their locale that can help them steer their way through the Anthropocene. The case study I present is therefore significant for operating outside what Pugh (2018, p. 103-104) identifies as the problematic “increasing emphasis on 'non-modern' and 'indigenous' knowledge in island resilience debates" that tends "to throw the violence of the Anthropocene back onto the island community, telling islanders that they need to draw upon their rich community resources in order to survive." No such tendency is present in Australia with regard to C.I., or on C.I. itself, as there is no sense in which the extractivist enterprise central to the island since its settlement is regarded as a "community resource" (Pugh, 2018, p. 104) that can inform diverse survival strategies, let alone any "generative, effective multi-species environmental justice" (Haraway, 2018, p. 105).

\section{The context of islands, island settlement, and extractivism}

Prior to European global maritime exploration and colonial expansion in the 15th-17th centuries, a large number of islands that were remote from continental mainlands (or from larger, inhabited islands), remained unvisited and uninhabited by humans. The eastern Indian and Pacific oceans, for instance, have a number of locations that show no evidence of human settlement prior to the arrival of Western explorers and colonists. For all intents and purposes, these islands can be considered to have been ecologically pristine at time of contact. The flora and fauna of islands derive from two sources. Some ancestral forms of current species may have been present when islands fragmented from larger terrestrial masses (often due to rising sea levels), being stranded on a parcel of land and being subject to processes of speciation in response to and/or competition with other species. Others arrived subsequent to the islands' islanding, either by air (as in the case of wind-blown seeds, flying insects, birds, or bats) or else by water, usually attached to floating material of various kinds. These processes may have resulted in extended periods of stability for species (at least while climate patterns stayed relatively constant and mega-events such as volcanic eruptions did not intrude) but the stable environments perceived by initial human visitors were effectively 'snapshots' of the environmental present of the islands at the visitors' moments of arrival. Our ability to perceive and research the impacts that have occurred on such islands over relatively short durations render these islands emblematic of the Anthropocene more generally and allow us to explore the operation of its various facets in focal locales.

As a recent aspect of the historical continuum sketched above, extractivism is a key component of the Anthropocene (Gómez-Barris, 2017). In general terms, extractivism refers to the activity of removing biomass (such as wood, sap, leaves, fruit, etc. or entire animals or 
parts thereof [skins, tusks, etc.]) or mineral deposits from a source location in order to trade them elsewhere. Extractivism differs from traditional approaches to subsistence harvesting or small-scale mining that have occurred in relatively sustainable manners by being conducted with minimal consideration of the impact of the activity and maximum emphasis on extraction in as speedy (and/or economically prudent) a manner as is possible. Over the last two centuries, extractivism has increasingly involved supplying materials for international trade and has thus been closely associated with (mid-late period) Western colonialism and, more recently, with neo-colonial continuations of previous imperial enterprises. Humans have been components in extractivist activities in various ways: as facilitators, managers, and economic beneficiaries of operations; as labourers whose activity forms part of the overall extractive 'machine'; as (direct and indirect) customers for products; and as residents of a planet whose environment has been altered by the extractive enterprise with regard to its emissions and waste products.

The founders of Island Biogeography (most notably Robert McArthur and Edward Wilson; Wilson, 2010) famously regarded islands as natural laboratories for observing speciation and the effects of introduced feral elements into eco-systems and even, on occasion, treated them as actual laboratories. Such perceptions and experiments have overwhelmingly addressed the biota that is confined to islands (unlike birds, flying insects, and semi-aquatic animals that can move on and off, to varying degrees). In the mid-20th century, this laboratorialist approach was also applied to human cultures on islands (see, for instance, Mead, 1957, or Vayda \& Rappaport, 1963). Such approaches have been substantially critiqued by researchers (such as Rainbird, 1999) on the basis that many islands were settled by populations that subsequently sought trade and other forms of contact with external communities and/or explored fresh territories after settling in an initial locale.

The unfashionability of the laboratory paradigm in Humanities and Social Sciences in recent decades has, however, obscured the extent to which islands (at least, some islands) can indeed serve as singular models to observe greater processes even when, as in the territory profiled in this article, the processes are idiosyncratic, complex, and disharmonious. As DiNapoli and Leppard (2018, p. 158) characterise in the introduction to their guest edited issue of the Journal of Island and Coastal Archaeology on 'Islands as Model Environments,' islands can provide significant insights into general processes that show complex human impacts on locales:

The nature of islands as particularly discrete and circumscribed terrestrial landscapes render them as distinct and simplified forms of more general kinds of habitat patches... This combination of inherent boundedness and the tremendous biogeographical variability of island sizes, climates, geologies, and marine and terrestrial ecologies provides a plethora of arrangements of environmental parameters in spatially delineated units. Comparative documentation and explanation of the varied prehistoric outcomes in these different environmental configurations yields model case studies of human ecodynamics.

While DiNapoli and Leppard propose this approach specifically for island pre-history, it is just as pertinent for discussion of the history, contexts, and unfolding of more recent ecodynamic practices and of their impacts in late/post-colonial, Anthropocene contexts. This is particularly the case since the consideration of particular islands in this context also facilitates 
a critique of the very notion of islands as being "circumscribed" in anything but terrestrial area. If any romantic notions of the unique 'apartness' of remote islands - as undisturbed remnants of a pre-colonial, pre-industrial past - linger on in island studies discourse, awareness of the all-embracing reach of the Anthropocene points to the need for such perceptions to be discarded in favour of more holistic understandings of islands and their ecological and economic operationality.

\section{Christmas Island and the context of late European imperialism}

C.I. is located 440 kilometres south of the western tip of the Indonesian island of Java (see Figure 1). The island is the peak of a volcanic seamount with a surface area of 135 square kilometres and comprises a thin, low coastal fringe, bordered by coral reefs, leading to steep escarpments and a high plateau with further raised areas that peak at 361 metres. Located on the southern fringe of the equatorial region, the island has a tropical climate. Uninhabited until 1888, the C.I. currently has a population of around 1,850 (Australian Bureau of Statistics, 2016), although this number is prone to rapid fluctuation due to factors discussed below. The island's economy is centred on extractivism, in the form of calcium phosphate mining, together with a small, nascent tourism sector.

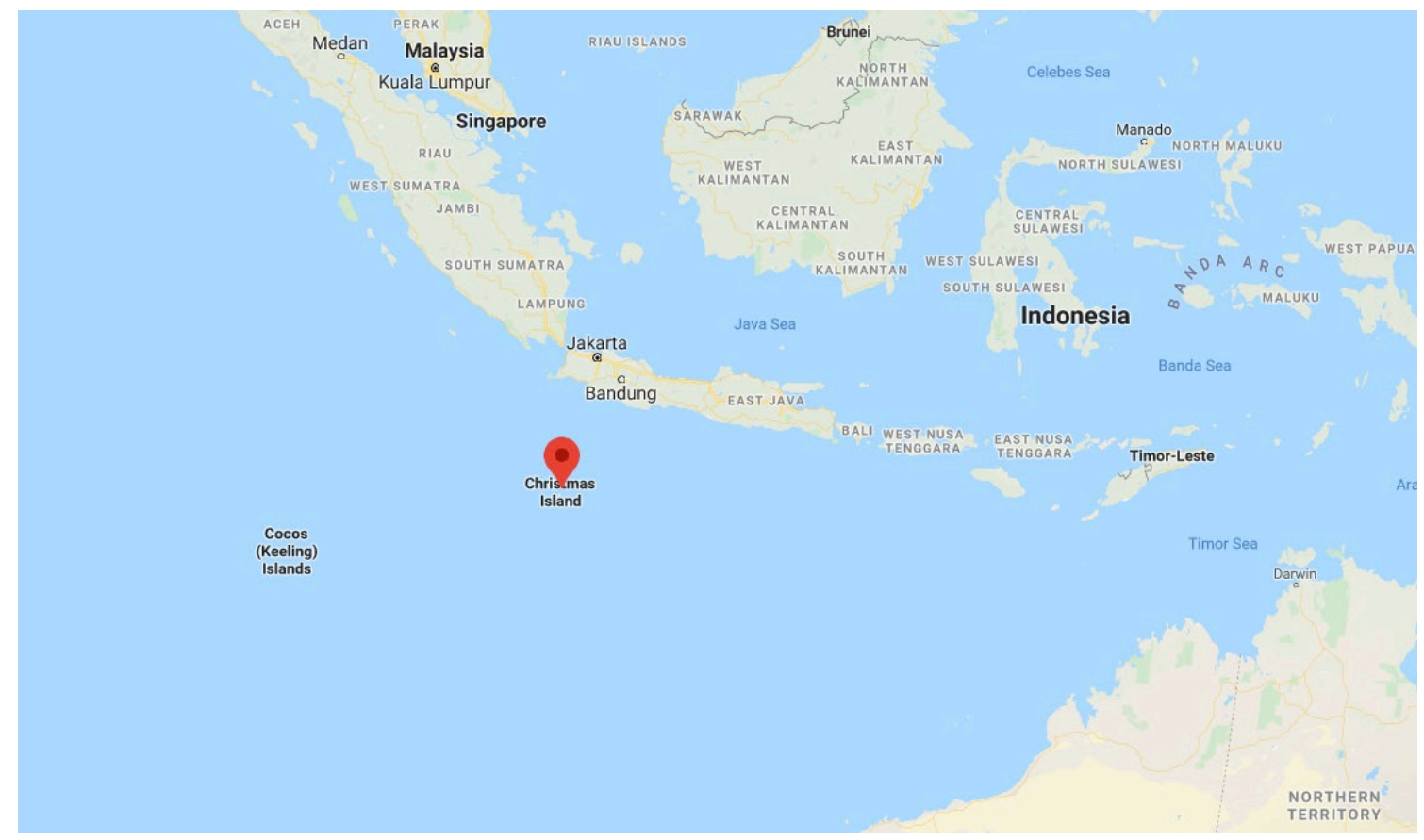

Figure 1. Map of Christmas Island's position in the north-eastern Indian Ocean (with the Australian mainland to the south-east). Source: Google Maps, 2020.

European mariners had known of C.I. since the early 17th century and a number of British ships sent exploratory parties ashore in the 1850s-1880s without showing any interest in claiming the uninhabited island. This situation changed in 1888 . When a survey led by British naturalist John Murray identified substantial deposits of calcium phosphate (principally in the form of carbonate-fluor-hydroxyapatite) on the upper plateau, the British Crown promptly moved to annex the territory. C.I.'s phosphates comprise ancient guano deposits 
and their derivatives. Trueman $(1965$, p. 7) has identified that the "phosphatization" of this material is "post-Miocene and probably Pleistocene in age" and that the deposition of the phosphate appears "to have taken place when the island formed a small, low-lying atoll, with little vegetation and an arid climate." In order for the guano to have been phosphatized in the volume existing on C.I., a number of other factors need to have aligned. The guano needed to have been deposited consistently and in large quantities over an extended duration, and the depositing birds would have had to have been relatively untroubled by predators such as mammals (or large reptiles). In addition, the terrain and substrata would need to be capable of holding accumulated deposits without substantial run-off or leaching, and low precipitation would assist in minimising the latter. These conditions appear to have been in place during the Pleistocene, allowing for the guano to transition into phosphate deposits that now occur as a surface covering of between 5-10 feet in un-mined areas (Trueman, 1965, p. 20) and as occasional rocky outcrops (whose weathering has produced the loose surface materials; Trueman, 1965, p. 38).

The extended time period of the deposition of guano and its transition into phosphates is in marked contrast to the rapid speed of extraction of the material once humans discovered it. Phosphate mining is a fairly recent extractivist enterprise. It commenced in England in 1847, in South Carolina (USA) in 1867, and developed as a major activity in Algeria and Tunisia in the 1890s (Ptáček, 2016, Chapter 8.1). The rapid spread of these enterprises followed the discovery that mineralised phosphates were effective plant fertilisers at a time when Western populations were rapidly increasing and putting pressure on an agricultural sector that was depleting available soils of necessary nutrients in cycles of diminishing returns. The relative ease of surface mining on C.I., the lack of any local population that might impede the activity, and the short distance from the deposits to the coast rendered exploitation of the local resource attractive and viable.

The discovery of phosphates led the ambitious Clunies-Ross family, who ran the Cocos-Keeling Islands, some 980 kilometres to the west, as a virtual fiefdom under the loose control of the British Straits Settlement at this time (Ackrill, 1984), to establish a small base on C.I. in order to position themselves for any future mining lease. In the period 1888-90, the family vied with Murray over rights to initiate commercial mining until they collaborated in establishing the C.I. Phosphate Company and gaining foreign investment in what Chambers (2011, p. 20) has described as "an exemplary case of the smooth transitions between exploration, science, and adventure capitalism, all enabled by the securing underwriting of the British Empire." Initial extraction was a low-volume and primarily artisanal activity but successive investments and introductions of new technologies, roads, and port facilities increasingly shifted it to an industrial enterprise superimposed on a previously pristine location.

Extractivism is not just an economic activity that has environmental impacts. It also has human ones. In the case of C.I., the need for labour resulted in around 200 Chinese indentured labourers, eight European managers, and a small number of others being transported to the island in 1898 to initiate mining, with the first phosphate output being shipped out in 1900. As the operation grew, more Chinese labourers were brought in to work in harsh conditions. The mining operation quietly accumulated profits for the company during the early 20th century, with its workers continuing in arduous employ (and with the majority of its phosphates being exported to Japan) and with minimal interest from its colonial administrators. While Japan gained direct access to the island when it invaded shortly after 
sweeping through Java in 1942 in the early stages of the Pacific War, the presence of its troops proved counter-productive, with sabotage and an uncommitted labour force resulting in mining dwindling to a standstill during the occupation period.

After the War, mining was taken over by the British Phosphate Commission, and in 1958 the British Crown detached C.I. from its Straits colony and transferred it to the Commonwealth of Australia. The majority population of the island then (as now) comprised descendants of initial ethnic Chinese workers (predominantly from China or Malaya), some Malays, and more recent and/or short-term Chinese migrants. Despite their numerical prominence, thes groups were significantly voiceless in the management of the island. Increasing local discontent with lack of workers' rights and lack of benefits enjoyed by Australian citizens on the national mainland led to the foundation of the Union of Christmas Island Workers (UCIW) in 1974. After a protracted campaign, the union won a parity of employment that also served to undermine the exploitative neo-colonial administration of the island. A decline in mining company profits resulting from fluctuations in the global phosphate market and increased wage costs led the eventual closure of the mine in 1987. This was then reversed in 1990 when former workers moved to establish Phosphate Resources Limited (PRL), taking over the mine facilities and leased areas (see Figure 2) and re-opening the mine in 1991. Since the early 1900s - and despite volatility in the international market mining has continued to be the principal economic activity on the island, generating $34 \%$ of gross product and employing $40 \%$ of the island's labour pool, in addition to requiring service industries that generate 38\% of gross product (Parliament of Australia, 2010, Chapter 3).

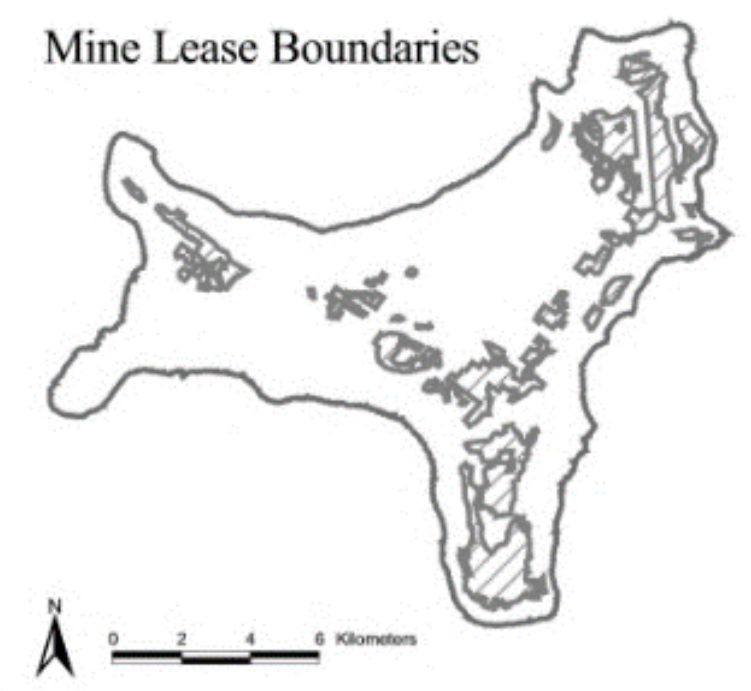

Figure 2. GeoScience Australia map of Christmas Island (with mining lease areas shaded in grey). Source: GIS Online, 2012.

Declining profitability, caused by market variations and the diminished resources in mine lease areas, led PRL to apply to the Australian Government in 2018 to clear an additional 7 hectares of the central plateau for test drilling to determine the extent and viability of phosphate deposits there. Despite support from the local administration, the proposal was somewhat surprisingly - rejected on environmental grounds by an Australian Government that had been closely affiliated with and supportive of mining interests since its election in 2013. This move caused considerable consternation amongst the large pro-mining lobby on the 
island, supported by the majority of the local Chinese-Australian community, as the decision was perceived to presage the end of mining within the next 10-15 years. In October 2019, political expediency was deployed in something of a stopgap measure when the Australian Government awarded PRL a contract to manage maintenance and property services at a very different - but equally problematic - local operation: the island's immigration detention centre.

Islands have long been used as temporary or longer-term incarceration sites for criminals, political dissidents, or refugees. As McCulloch (2007, pp. 3-4) has identified, the geography of islands "cut off from the mainland and by implication the mainstream of life, captures the radical separation of prisoners and prisons from outside society." This aspect has risen in prominence over the last two decades as international flows of refugees fleeing conflict or other crisis zones has increased, and various facets of this have been addressed in publications such as Mountz and Briskman's edited theme section on 'Island Detentions' in Shima (2012). With particular regard to C.I., Briskman, Fiske, and Dimasi (2012) have examined the general impact of the detention centre on the Christmas Islanders, and Brady (2018) has reflected on the experience of internees and their support staff.

The establishment of an immigration detention centre on C.I. reflected geo-political factors arising from instability in the Middle East and Central Asia (in particular) in the late 1980s and early 1990s, as well as C.I.'s location close to Java. These factors have led a number of refugees from conflict zones to seek passage to Australia using the services of Indonesian people smugglers. As the nearest Australian territory to Indonesia (along with the Ashmore and Cartier Islands, 1900 kilometres to the east), C.I. was targeted by an initial trickle of asylum seekers who arrived in 2001. As a country that had experienced a previous wave of boat-borne asylum seekers in 1976-78 (from Vietnam, in the final stages of its protracted conflict), there was little initial alarm on the Australian mainland about these arrivals. The situation changed dramatically in August 2001 when the Australian government manufactured a "crisis" over Asian refugees arriving by sea (O'Doherty \& Augoustinos, 2008). Such perceptions were heightened by the events of September 11, 2001, and by fears of jihadi terrorists entering Australia by boat. One Australian Government response specifically aimed to counter Christmas, Ashmore, and Cartier Islands' easy access for people smugglers by creating exclusion areas around them (under the Australian Government's Migration Amendment [Excision from Migration Zone] Act 2001), effectively creating a dual tier of Australian territory, with a number of locations forming a buffer zone between Australia and the "other" of Asia.

The Australian Government sought to show its resolve and its estimate of the scale of the "problem" by announcing the construction of a detention centre capable of holding 1200 arrivals on C.I. (although by the time the construction tender was approved, the limited scale of actual arrivals led the specifications of the centre to be downsized to house 800). The centre was constructed on a 40 hectare ( 99 acre) site formerly mined for phosphates in the north east of the island. The centre was completed in 2008 and operated until 2017, before closing when the number of people smuggler boats had significantly declined. The centre was then reopened by the Australian Government in February 2019, despite there being no apparent need, and stayed open, despite minimal occupancy, until a temporary use was found in early 2020 when it was used as a quarantine facility for Australians returning to the country from COVID-19 'hot-spots' in China. As a result, PRL has benefitted from a contract to maintain property on a barely used government asset.

At present, C.I. looks to an uncertain future in economic terms with the mining 
operation expected to terminate within 10-20 years, when the remaining lease areas will become effectively exhausted. Given the highly limited number of asylum seekers housed at the detention centre, it is unlikely that this operation will be used anything more than sporadically. C.I.'s principal potential alternative enterprise, tourism, has been touted for several decades (including during the period 1993-98, in which a casino operated on the island mainly catering to Indonesian 'high-rollers') and has been subject to increasing promotion since 2010 but faces major issues in an environment that has been heavily affected by surface mining and the construction of related facilities.

\section{Eco-tourism, extractivism, and the experience economy of Christmas Island}

Those areas of C.I.'s central plateau that have not been cleared for surface mining are dominated by evergreen rainforests, with semi-deciduous rainforest species on the slopes and terraces surrounding the plateau and small pockets of other vegetation types on coastal strips and small wetland areas. The terrain and forest types provide attractive nesting sites for a variety of seabirds, including types of regionally endangered boobies such as the Abbott's booby (Papasula abbotti) and the Christmas Island Frigatebird (Fregata andrewsi), and have also provided a particularly hospitable environment for crustaceans to flourish. Twenty-two species of crustaceans have been recorded on C.I. to date, including the prolific small Christmas Island red crab (Gecarcoidea natalis) and the large Coconut crab (Birgus latro; "robber crab"). There are estimated to be around 50 million red crabs on C.I., living in the forested plateau area for the majority of the year but migrating to the sea en masse to spawn at the beginning of the wet season. The resultant so-called "red tide" moves across roads and through properties, along routes established in the pre-human era, in what is now an annual distraction to traffic flows and to everyday human life. Equally well-known are the robber crabs, the world's largest terrestrial crustacean. While the species is found across the central Indian Ocean and in the west and central Pacific, C.I. adult robber crabs are exceptionally large, growing up to 4 kilograms in weight and measuring up to 40 centimetres in length, with a leg span of around 80 centimetres (see Figure 3). In addition to its rare seabirds and renowned crustaceans, C.I. is also surrounded by a narrow fringing reef with a variety of coral and fish species, and the deep waters that rapidly drop off past the reef are populated by species such as rays, barracuda, marlin, and swordfish.

As the brief inventory of flora and fauna sketched above suggests, C.I. has considerable potential as a nature-oriented tourism destination. Indeed, given the minimal nature of hotel or other leisure facilities on the island (beyond a small golf course), the environment is the major drawcard for visitors and has been heavily promoted by the C.I. Tourism Association through leaflets, advertisements, and web pages. Exploration of natural assets is a key facet of the 'experience economy' the island's tourism boosters wish to promote. The notion of the 'experience economy' was first developed by Pine and Gilmore (1999) to refer to commercial operations facilitating memorable experiences for consumers rather than simply delivering services to them. Key to Pine and Gilmore's concept is that experiences enacted within the 'experience economy' should be variously educational and/or transformative, providing 'value adding' to the basic service commodity provided by businesses (Pine \& Gilmore, 1999). In tourism, this has led to emphases on active exploration of local environments and experiences on offer (see Andersson, 2007, for discussion). The potential for tourists to 
experience C.I.'s natural assets has been bolstered by a succession of measures, including the designation of $63 \%$ of the island as a national park as a result of extensions to Section 7 of the Australian National Parks and Wildlife Conservation Act 1975 passed in 1980, 1986, and 1989. Yet, there is significant disparity between the areas of the island protected by such designations (and represented in promotional literature and audio-visual material) and actual experience of the island as a visitor. While the island's flora and fauna are impressive, and while there are areas of unspoiled natural beauty, they are in stark - and abrupt - contrast to mining areas and to the transport routes that link the latter to port facilities. While the "human-natural systems" of the island may be "coupled" (Fitzhugh et al., 2018, p. 1077, the coupling is an uneasy and fraught one. Similarly, while what DiNapoli and Leppard (2018, p. 157) identify as the "particularly discrete and circumscribed terrestrial landscapes" of islands are in evidence on C.I., they are less integrations of natural areas and the "cultural landscapes" created by human management of the environment for sustained livelihood activities (UNESCO, 2011) than Anthropocene conflict zones caused by extractivism. The assemblage of the island is, therefore, a dynamic one in which endogenous species are assailed by various exogenous ones and, in the case of humans, the technologies they bring with them.

In order to achieve some understanding of Anthropocene impacts on C.I., it is useful to try and think through the predicament of native species and attempt to understand their conditions and general plight in addition to considering them as phenomena experienced by locals, temporary detention centre workers, tourists, and researchers. Let's begin with an encounter. Figure 3 provides an image that illustrates a key aspect of the island's appeal to tourists, and the context of its production illustrates the tensions underlying that appeal. The image illustrates the potential for visitors to have direct encounters with charismatic megacrustaceans and, indeed, was a 'special moment' for the human depicted in the image (the author, photographed by a partner). Posted on my Facebook page, it received the most likes and most comments of any image I had previously posted. While shot on a mobile phone, it recorded something of an archetypal 'Kodak moment' for me. Yet, it was no fortuitous snapshot. Visitors to C.I. most often encounter robber crabs in one of two contexts, as individuals on roads or roadsides, or as small, shell 'pancakes' flattened into the tarmac by motor vehicles. In this regard, Figure 3 represents an encounter fraught with anxiety. Seeing a large robber crab on the hard shoulder of North-South Baseline Road (which connects the mining area on the southern peninsula to the developed north of the island) and being aware of a regular stream of trucks driving up that road, my partner and I stopped so that I could deflect the creature back into the bush. Manoeuvring myself alongside the crab, I blocked its way, causing it to reverse direction and I then paused for a photo alongside it before gently pushing it back into the undergrowth. Whatever relief I felt at this act was undermined by the knowledge that the crab might well return to the road immediately after we left, and that all along the Baseline Road, and other roads across the island, crabs were being squashed by fast moving vehicles every day. Far from being an eco-paradise, the roadways of C.I. represent killing fields for crustaceans - whatever the degree of signage urging careful driving (see Figure 4) and varying degrees of driver compliance with that guidance. If the Anthropocene represents a period when humans have a dominant influence on the environment, then Baseline Road (and, by association, other similar roads) represents the Anthropocene in action in micro, facilitating the conversion of living crustaceans to thin strips of compressed chitin and extruded fluids as collateral damage arising from the simple, everyday operation of a 
extractivist enterprise. As this brief cameo should illustrate, the experiences of, and along, this route are part of a particularly confronting economy on the island.

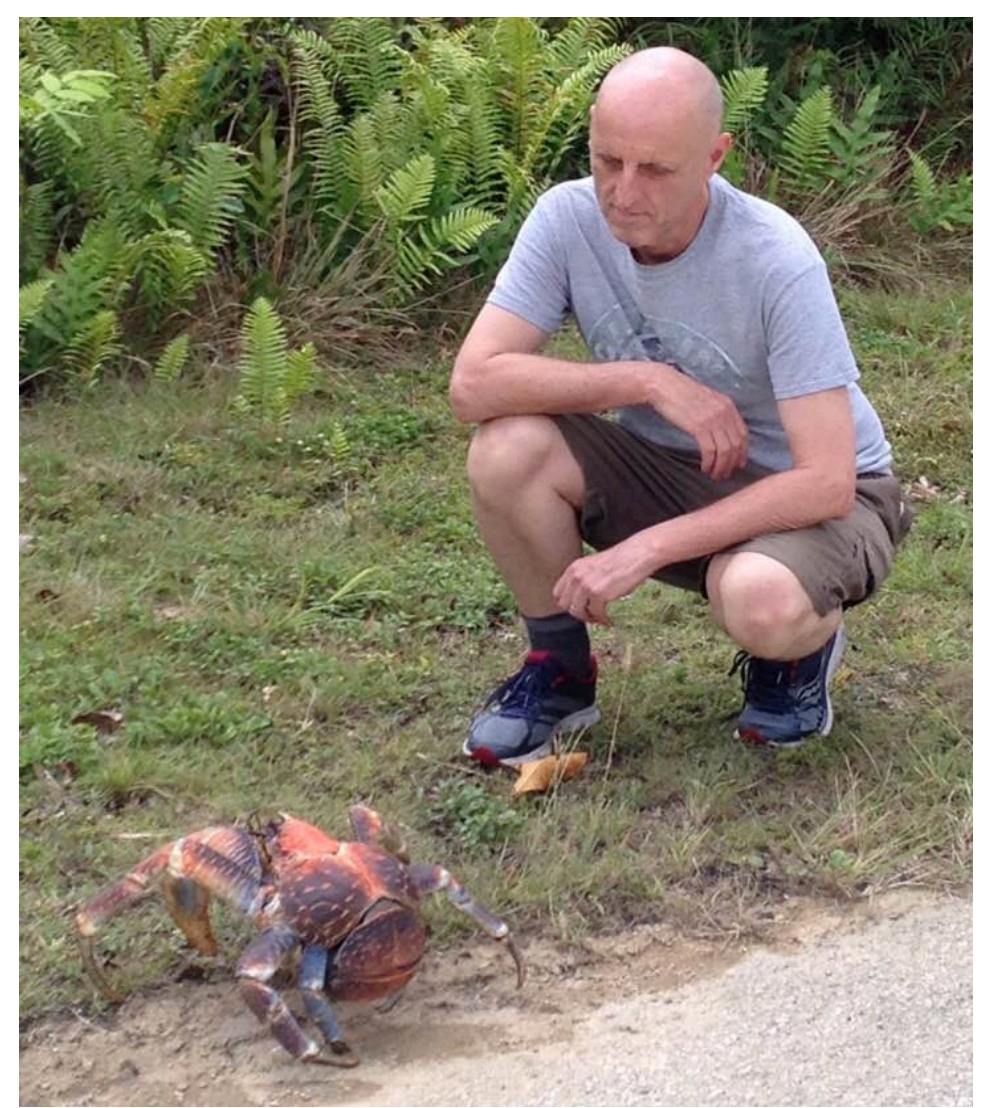

Figure 3. Robber crab and author, July 2018. Source: Alison Rahn, 2018.

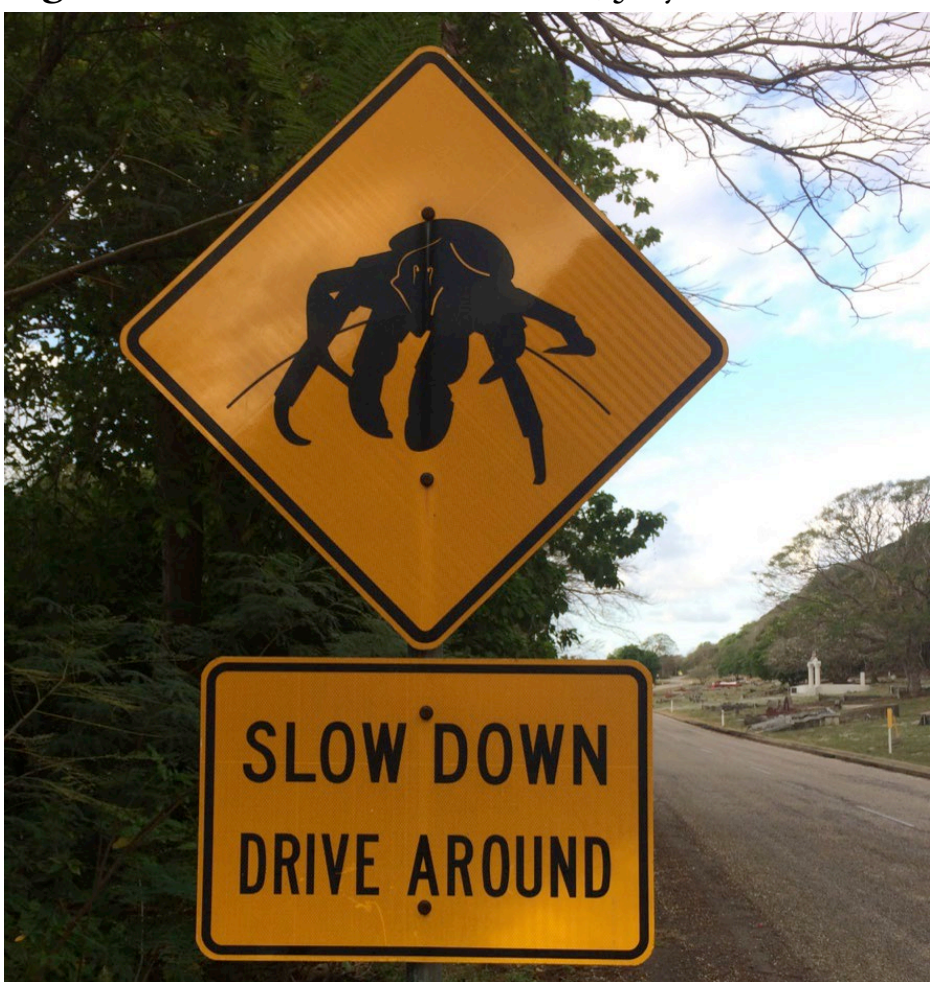

Figure 4. Road sign instructing drivers to avoid running over robber crabs. Source: Philip Hayward, 2018. 
Driving north from the photo site discussed above, we approached the detention centre, getting as far as the main entrance car park before an official came out of a building and headed towards our vehicle. We hurriedly departed after taking a couple of quick snapshots. As grim and inhumane as it is, the detention centre has a richly ironic aspect - at least for the current discussion - in that while its raison d'etre is to prevent and deter the free movement of human individuals across national borders, its architects and planners were required to accommodate red crab movement across the island when designing the facility. As Chambers (2011, p. 33) elegantly identified:

In the first instance, a site was chosen away from the crabs' main migratory route. But the design brief also mandated the construction of special "crab crossing facilities" for those creatures that did stray close to the facility. For them, special channels, directing and ensuring their orderly and secure migration across the island, were duly constructed. Here, surely, both a government's dream and the absurdity of its fulfillment are united in one gesture. It is a dream of orderly migration in which even red crabs are induced to follow the migratory routes designed by the experienced architects of prisons and reinforced with concrete.

While I was aware of this factor, I also noticed the tell-tale small marks that represented crushed red crabs along the approach road to the centre and the unvarying speeds of centre vehicles travelling along the road. In such contexts, human interaction with local fauna varies according to the degree of importance accorded to it. While tourists may have time to carefully manoeuvre around crabs on the island's roads, detention centre and mining staff clearly regard their priorities and schedules as more important than ecological concerns. To make matters worse, this indifferent, vehicular carnage is accompanied by another onslaught on the species: that caused by the introduction and recent proliferation of an invasive insect, the yellow crazy ant (Anoplolepis gracilipes).

The impact of the crazy ants on the island's red crabs illustrates a phenomenon that Hill and Hadly (2018, para. 1) have identified in the following terms:

"The Anthropocene" is challenging the established conceptions of biogeography. In an age of widespread disturbance, global commerce, and a rapidly changing climate, some species have the opportunity to access new, vast areas while others disappear at unprecedented rates and scales, along with the environments to which they are adapted.

Key to Hill and Hadly's characterisation is that the old, slow-paced speciation occurring within species naturalised to isolated (island/'islanded') environments over extended periods - (often) without significant external disruption - has been superseded by rapid and dramatic transitions, including the introductions of species that may become invasive. Invasivity in this context includes a variety of associated phenomena: squeezing species out of ecological niches by outcompeting them; incidentally disrupting environments in manners that are disadvantageous to natives; having defensive behaviours that are harmful to established species; or actively attacking and/or devouring native fauna. As should be apparent, humans are both (deliberate and incidental) facilitators of invasivity, in general, and are also a mammalian component of the overall invasive system. This Anthropocene phenomenon has led to the development of the field of 
Invasion Biology. This approach was first presented in cohesive form in Elton's The Ecology of Invasions by Animals and Plants (1958) but gained considerable traction in the late 1900s and early 2000s, leading to more nuanced and holistic overviews that acknowledged the complexity of the Anthropocene, such as Hui and Richardson (2017). At the same time, the field has been critiqued and interpreted in a variety of ways - including a denial akin to climate change denialism (see Courchamp et al., 2017, and Frank, 2019, for outlines and critiques of such approaches) and attempts to either fold Invasion Biology into the more general field of synecology (the study of species interaction in a variety of contexts, also referred to as 'community ecology'; e.g., Davis, 2009) or to substantially dismantle it by questioning the very notion of natives and/versus invasives in the Anthropocene (e.g., Hill \& Hadly, 2018).

Whatever philosophical or disciplinary position one adopts on the nature of invasion biology with regard to Anthropocene synecology, C.I. offers a vivid example of the impact of invasives on natives with the regard to crazy ants' impacts upon red crabs. It is unclear when crazy ants first arrived on C.I., with the period between 1915-1934 being often cited for its introduction (Parks Australia, 2015). Given that there is no evidence that the species was consciously introduced, it seems likely that the ants were conveyed to the island in shipping cargo. For much of the 20th century, the ants were present in small numbers and were not regarded as a particular problem. This changed in the 1990s when the population exploded and huge 'super-colonies' of ants began to be discovered in the island's interior, one colony alone measuring 750 hectares in size, representing around 7.5 billion ants, and with an equivalent amount estimated to be foraging in the surrounding tree canopy (Parks Australia, 2015). This explosion seems to be connected to a similar rise in numbers in another accidentally introduced invasive species, the Tachardina aurantiaca (Kerriidae) scale insect. The association is that the scale insect produces a sugar-rich secretion as a by-product of its digestive system that has become a prime food source for the ants (Green et al., 2014).

The crazy ant colonies have impacted the island environment through a chain of effects. The most dramatic of these has been their impact on the omnivorous red crab through their capacity to spray formic acid from their abdomen as a defence mechanism, causing blindness and inflamed joints in crabs that rapidly kills them (and can even incapacitate the considerably larger robber crab). It is estimated that around 40 million red crabs have killed by ants since the 1990s (Joyner, 2019). The removal of red crabs from various areas of the island has also had an impact on forest vegetation, as the crabs play a valuable role in local ecology by removing leaf litter, and aerating the soil (by foraging and burrowing) and fertilising it with excreta (see Figure 5). At time of writing (April 2020), efforts are being made to introduce yet another external species, the Malaysian micro-wasp (Tachardiaephagus somervillei) to counter the ants. The micro-wasp kills scale insects by laying eggs in their bodies and it is hoped that their proliferation will diminish the scale insects, which are ants' primary food source. While the outcome is, as yet, unknown, the succession of interrelations of introduced species illustrates the complexity of ecological relations in the Anthropocene. This attempt to counter one invasive species with another might be seen to be motivated by an attempt to achieve some degree of environmental "justice" by diminishing the crazy ants' assault on red crabs (although "justice" is not a term that the ants might call to mind - if they could conceive of such a notion - when their supply of scale insects begins to diminish). 


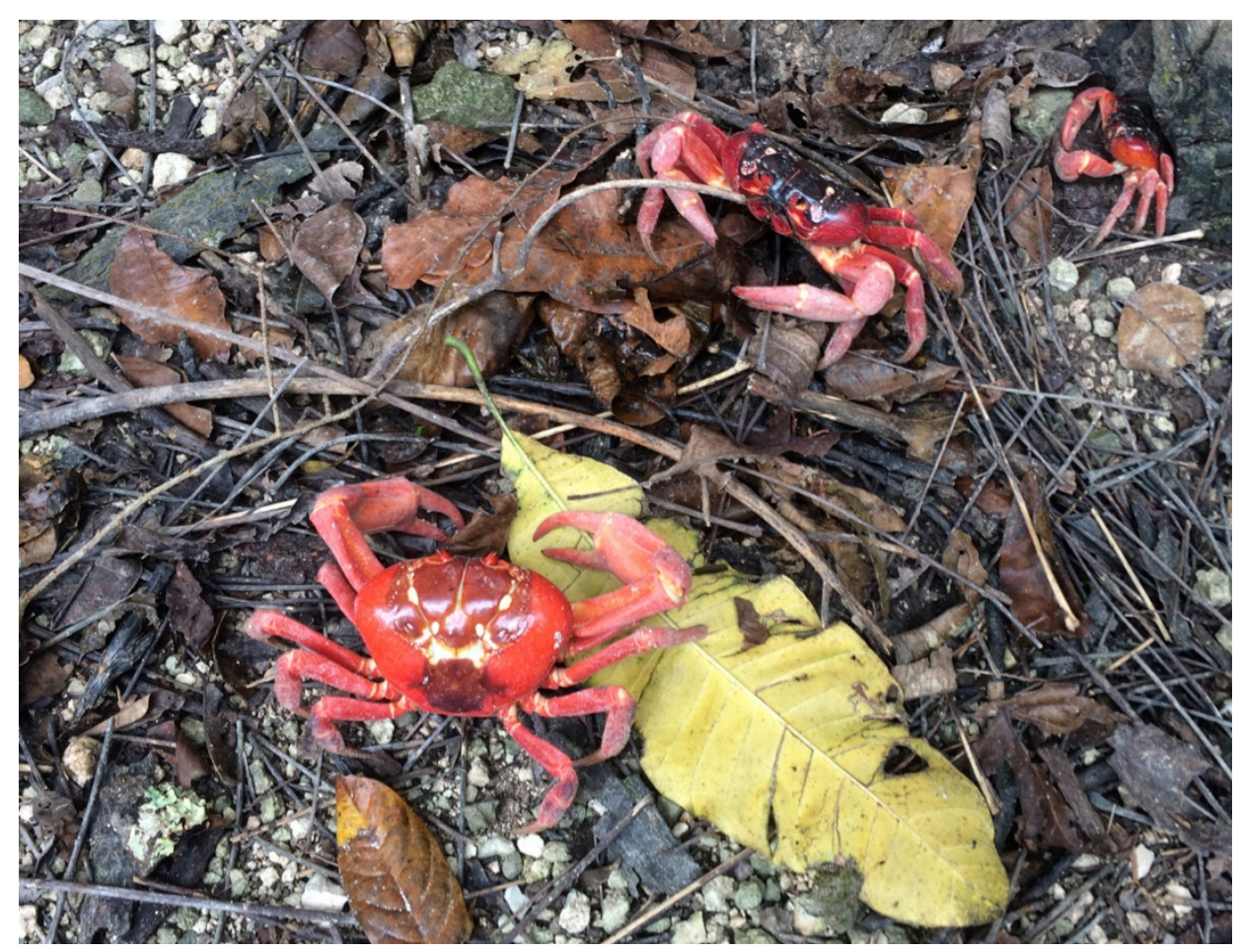

Figure 5. Red crabs processing leaf litter. Source: Philip Hayward, 2018.

The island's plateau also highlights another aspect of the ongoing impact of mining and of the abandonment of previous mining sites. Despite the C.I. mining company's emphasis on remediation on its website (Phosphate Resources Limited, 2017), a number of former mining areas, now de-restricted and allowing public access for those prepared to wander offtrack, are almost entirely covered by invasive shrubs and vines that have managed to gain purchase in areas whose topsoils have been massively depleted by open mining (Swarbrick, 1997), making the areas inhospitable to island crustaceans and other native fauna.

It is possible to gain access to areas of the island in which native flora and fauna predominate, and these are the locales most frequently shown in promotional visual and audio-visual media. Some areas of the national park are relatively free of invasives, and many of the steep tracks that drop off from the plateau to the coast are accessible to hardy hikers or by four-wheel drive vehicles. These routes provide opportunities to explore various types of island flora and for visitors to negotiate their way through an abundance of crustaceans. A number of vantage points also offer opportunities to observe frigate birds and boobies in flight. Indeed, with the establishment of the small Swell Lodge eco-resort within the national park, close to the scenic Dales area on the east coast, in 2018, the island now offers a small number of affluent tourists the opportunity to enjoy the unspoilt environment its promotional material promises (see, e.g., Christmas Island Tourism's YouTube Channel [n.d.]).

Beaches are somewhat more problematic. While tiny, unspoilt areas such as Dolly, Greta, and Lily Beaches on the east coast are accessible to the adventurous, the island's most sizeable beach is the colourfully named Flying Fish Cove. Indeed, Parks Australia (2020) has a webpage dedicated to what it identifies as "Christmas Island's most popular beach" that details that spinner dolphins (Stenella longirostris) can often be glimpsed offshore. While this may be true - and while the webpage may show an inviting image of the south-western tip of the beach - the reality is more complex. Indeed, a sublime grinding of perceptual gears is 
necessary for the visitor to reconcile such characterisations with experience of the remainder of the small cove whose hemispherical beach stretches for about 850 metres. At the northern end is an aggregation of phosphate wharves, a warehouse, and crane (see Figure 6). Phosphate freighters enter the bay and moor at the wharves on a regular basis to load their cargo. While the port has a tourist appeal, of the type represented by UNESCO's category of "Industrial Heritage sites" - such as those of Chile's Valparaíso port (UNESCO, 2013) with its distinctive waterfront facilities - this appeal is not easily mapped on to either eco-tourism or more conventional beachside leisure. Local tourism entrepreneurs seem to have become inured to the situation, blithely telling visitors to the island (such as myself) that the beach is a "great swimming spot" and that there is no need to be anxious at the arrival of freight ships at the wharf as they will "usually" sound their horns to warn swimmers as they approach the jetty.

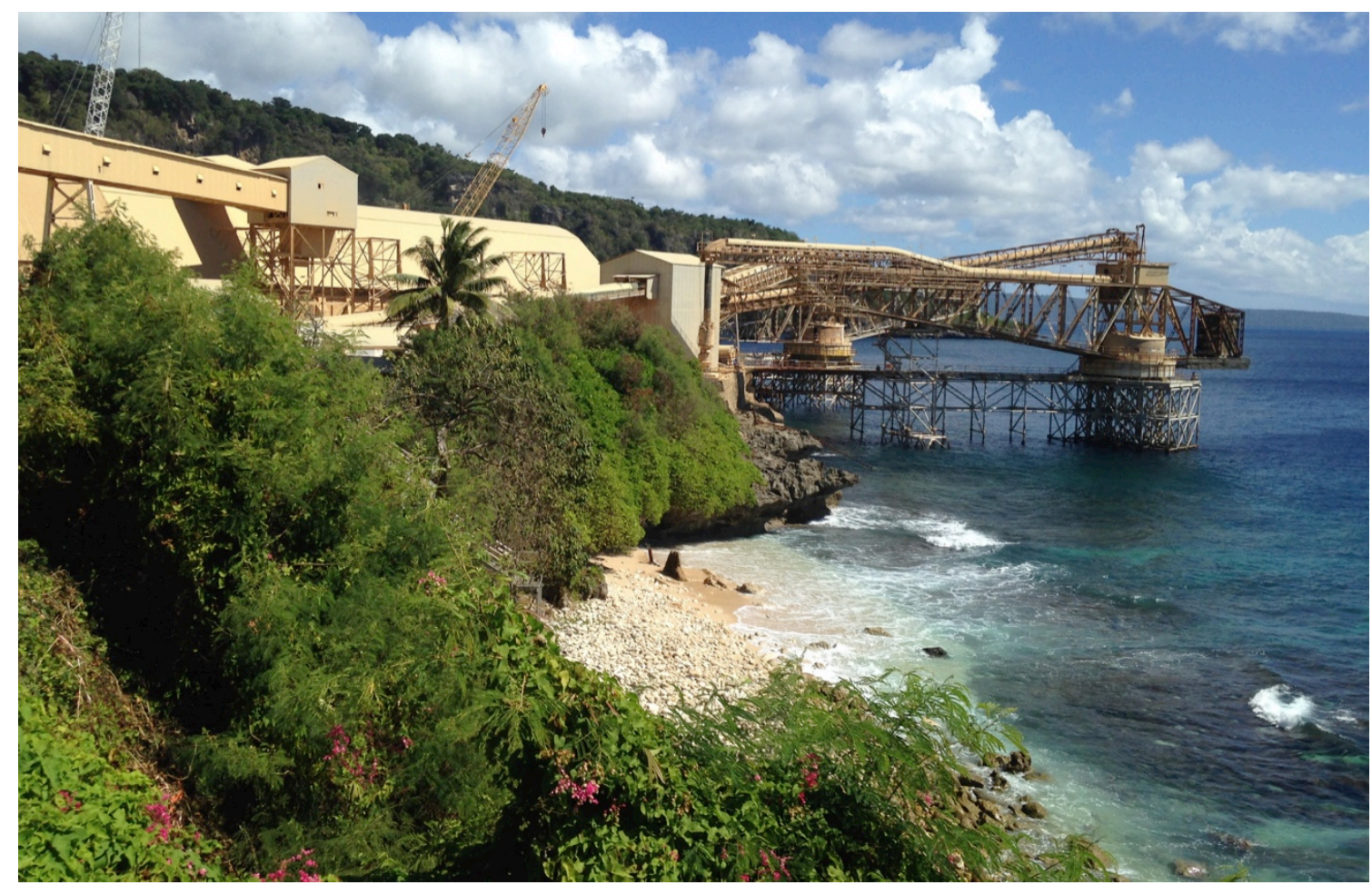

Figure 6. Phosphate loading facility, Flying Fish Cove (and expanse of invasive vegetation along coastal slopes). Source: Alison Rahn, 2018.

There is more to the awkward conjunction of perceptions and usages sketched above than might at first appear. Small islands, by definition, have a limited range of landscapes, beaches, safe anchorages, etc., and often a small range of resources that can sustain the types of capitalist enterprises that have led them to be settled. Put simply, islanders have to do the best with what they have, and it is understandable if this involves selective blindness to aspects of the island that might appear to outsiders. Again, put simply, the island's 'experience economy' can be perceived and experienced very differently by insiders and outsiders, using - or, more accurately, requiring - various perceptual filters in order to promote particular visions of the locale. As Lichrou and O'Malley (2006, p. 37) contend with regard to the marketing of Milos (an Aegean island with a long history of mining) as a tourist destination, "the 'reality' of a place is constructed through contested and actively involving processes [...] as different individuals and groups of interests are making efforts to legitimize $[\ldots]$ and promote their 
view of a 'preferred reality'," with the most powerful groups usually determining the latter. The difficulty, of course, is that the "preferred reality" of island stakeholders at any given point is not easily imposed upon tourists, environmentalists, or other external agents.

\section{Conclusion}

Aspects of C.I. such as the incongruous multiple perception and designation of Flying Fish Cove not only accord with DiNapoli and Leppard's (2018, p. 158) characterisation of the "plethora of arrangements of environmental parameters in spatially delineated units" in islands, in general, but also allow this characterisation to be used in a manner not envisaged by the authors, i.e., with regard to individual "spatially delineated units" that can provide "model case studies of human ecodynamics" (2018, p. 158). Islands such as C.I. can be perceived palimpsestically: parts of them comprise 'over-writings' of various kinds that require active negotiation to comprehend. Comprehension of such subtleties of human categorisation and comprehension of environmental use is, of course, specific to humans; the crustacean experience of C.I. is likely to be very different. While Clifford (1997, p. 326) speculated as to whether sea otters have any sense of the profound modification to their environment in the Anthropocene that might be regarded as "historical"; there is probably little to be gained in seeking to project such human concepts onto crustaceans. If we understand "economy" in its loosest sense, in a manner that allows us to include crustaceans' foraging lifestyles as (nontransactional) 'subsistence' activities, we can however glimpse an 'experience economy' at work as the creatures encounter highly aggressive crazy ants and car and truck tires as they roam in areas that were once hospitable. While they may be incapable of conceiving it as such, the Anthropocene is their everyday reality, their 'new normal' and consideration of it involves addressing "processes of stability, resilience, and change" in their "socio-ecological relationships or systems" (Fitzhugh et al., 2018, p. 1077. In this regard, the everyday reality of C.I.'s crustaceans is closely coupled with the dominant industrial-mineralogical dynamic of the island that prioritises itself over all other factors.

Any attempt to comprehend the complex operation of the island in order to engage with particular manifestations of the Anthropocene and to restore any semblance of previous environmental balance must, necessarily, address the phases of its history rather than just its disturbed present. Within this perspective, there are grounds for optimism. Mining on C.I. is in its final stages. The activity will terminate either when all phosphate areas are depleted, or else when present areas are depleted and when no further mining leases are granted. Unless the island is to be depopulated (a possibility, but one incommensurate with Australia's strategic interest in maintaining the territory and the Economic Exclusion Zone encircling it), alternate economic activities will have to be developed. Moral and humanitarian issues aside, the internment camp offers one option, but the volume of 'clientele' is unpredictable and its cost to the Australian Government is not insignificant. Tourism, and eco-tourism, in particular, look to be an attractive option (at least, when COVID-19 diminishes and if there is a return to convenient and affordable travel to the island). Such a reorientation also offers another potential enterprise in the form of the remediation works necessary to restore former mining sites to states that can facilitate their re-inhabitation by endogenous species. Somewhat fortuitously, the inbuilt retirement dates of extractivist enterprises such as C.I.'s open surface phosphate deposits can be perceived as advantageous to the endogenous species that they have assailed. 
As this reflective essay has established, small islands such as C.I. are far more than 'laboratories' in which we can dispassionately observe the unfolding of the Anthropocene in particularly determined locales. C.I. - and other small islands (such as Banaban, Bougainville, or Nauru, to name but three) - offer vivid, microcosmic vignettes of the conflicts brought into play by extractivism, just as the low-lying islands of Kiribati, Tuvalu, and the Maldives vividly illustrate the impact of rising sea levels resulting from global warming. These, and many other islands across the planet, are currently experiencing rapid and far-reaching changes that affect the biomasses of their terrestrial and maritime components. Indeed, as I have argued elsewhere, to be an islander is - increasingly - to live in flux (Hayward, 2018). Similarly, if island studies is to fully engage with the complexity of its object of study, it must address flux as a key disciplinary orientation. In this regard, islands are far more than emblems of the Anthropocene. The visceral interactions that occur within the overall assemblage of islands embody the Anthropocene experience. Similarly, processes of "making kin" (Haraway, 2016) with non-human species are vital to modifying the experiences and futures of islands and islanders, and involve direct consideration and accommodation of the presence of nonhuman fauna and flora alike. As Clifford (1997, p. 302) reminds us, economic, political, environmental, social, and cultural forces "are materialized as historical reality only through particular local projects and stories," and it is the task of island studies to develop, analyse, and relate specific local experiences in order to form compelling narratives that can inform global debate and action.

\section{Acknowledgements}

Thanks to Alison Rahn for accompanying me on field work and to Joseph Cheer, Jonathan Pugh, and the anonymous ISJ referees for their informative feedback on earlier drafts of this article.

\section{References}

Ackrill, M. (1984). The origins and nature of the first permanent settlement on the CocosKeeling Islands. Australian Historical Studies, 21, 229-294. https://doi.org/10.1080/10314618408595703

Australian Bureau of Statistics. (2016). Christmas Island. 2016 Census QuickStats. https://quickstats.censusdata.abs.gov.au/census services/getproduct/census/2016/qui ckstat/SSC90001?opendocument

Bennett, J. (2010). Vibrant matter: A political ecology of things. Duke University Press.

Brady, G. (2018). The island of hungry ghosts [Documentary film].

Briskman, L., Fiske, L., \& Dimasi, M. (2012). The impact of Australian asylum seeker policy on Christmas Islanders (2001-2011). Shima: The International Journal of Research into Island Cultures, 6(2), 99-115.

Chambers, P. (2011). Society has been defended: following the shifting shape of state through Australia's Christmas Island. International Political Sociology, 5, 18-34. https://doi.org/10.1111/j.1749-5687.2011.00118.x

Christmas Island Tourism. (n.d.). Videos [YouTube channel]. https://www.youtube.com/user/ChristmasIsTourism/videos 
Clifford, J. (1997). Fort Ross meditation. In Clifford, J. Routes: travel and translation in the late twentieth century. Harvard University Press.

Courchamp, F., Fournier, A., Bellard, C. et al. (2017). Invasion biology: specific problems and possible solutions. Trends in Ecology and Evolution, 32(10), 13-22. https://doi.org/10.1016/j.tree.2016.11.001

Davis, M. (2009). Invasion biology. Oxford University Press.

DiNapoli, R., \& Leppard, T.P. (2018). Islands as model environments. The Journal of Island and Coastal Archaeology, 13, 157-160.

https://doi.org/10.1080/15564894.2017.1311285

Fitzhugh, B., Butler, V.L., Bovy, K.M., \& Etnier, M.A. (2018). Human ecodynamics: A perspective for the study of long-term change in socioecological systems. Journal of Archaeological Science: Reports, 23, 1077-1094.

https://doi.org/10.1016/j.jasrep.2018.03.016

Frank, D.M. (2019). Disagreement or denialism? "Invasive species denialism" and ethical disagreement in science. Synthese. https://doi.org/10.1007/s11229-019-02259-w

Gómez-Barris, M. (2017). The extractive zone: social ecologies and decolonial perspectives. Duke University Press.

Green, P., O’Dowd, D.J., \& Neumann, G. (2014). Application to release the microhymenopteran parasitoid Tachardiaephagus somervillei for the control of the invasive scale insect Tachardina aurantiaca on Christmas Island, Indian Ocean. Australian Government Department of Agriculture. https://scholars.latrobe.edu.au/display/publication39188

Haraway, D. (2018). Staying with the trouble for multispecies environmental justice. Dialogues in Human Geography, 8(1), 102-105. https://doi.org/10.1177/2043820617739208

Haraway, D. (2016). Staying with the trouble: making kin in the Chthulucene. Duke University Press.

Haraway, D. (2015). Anthropocene, Capitalocene, Plantationocene, Chthulucene: making kin. Environmental Humanities, 6(1). https://doi.org/10.1215/22011919-3615934

Hayward, P. (2018, March 30-April 1). Keynote: Formulations in flux [Conference presentation]. Archipelagos and Aquapelagos - Conceptualising Islands and Marine Spaces Conference, Pratt Institute, Brooklyn, New York, USA.

Hayward, P. (2012). Aquapelagos and aquapelagic assemblages. Shima, 6(2), 1-14.

Hill, A.P., \& Hadly, E.A. (2018, July 16). Rethinking "native" in the Anthropocene. Frontiers in Earth Science, 6, 96. https://doi.org/10.3389/feart.2018.00096

Joyner, T. (2019, January 16). Tiny wasps show some success in fight to save Christmas Island's red crabs from crazy ants. ABC News. https://www.abc.net.au/news/2019-01-16/waspsenlisted-to-control-crazy-ants-on-christmas-island/10666868

Lichrou, M., \& O'Malley, L. (2006). Mining and tourism: conflicts in the marketing of Milos Island as a tourism destination. Tourism and Hospitality Planning \& Development, 3(1), 3546. https://10.1080/14790530600640834

McCulloch, J. (2007, June 30). Christmas Island detention centre [Conference paper]. 6th Sisters Inside Conference, Sydney, Australia.

http://www.sistersinside.com.au/media/conference2007/JudeMccullock.doc (retrieved 5th July 2020) 
Mead, M. (1957). Introduction to Polynesia as a laboratory for the development of models in the study of cultural evolution. Journal of the Polynesian Society, 66, 145.

Mountz, A., \& Briskman, L. (Eds.). (2012). Detention islands. Shima: The International Journal of Research into Island Cultures, 6(2), 21-137.

O'Doherty, K., \& Augoustinos, M. (2008). Protecting the nation: nationalist rhetoric on asylum seekers and the Tampa. Community and Applied Social Psychology, 18(6), 576592. https://doi.org/10.1002/casp. 973

Parks Australia (2020). Flying Fish Cove. Christmas Island National Park. https://parksaustralia.gov.au/christmas/do/beaches/flying-fish-cove/

Parks Australia (2015). Christmas Island yellow crazy ant control program moving from chemical control to a biological control future.

https://www.environment.gov.au/system/files/resources/898583db-b929-491a8448-73fb652bca66/files/brochure-detail-crazy-ant-control-options.pdf

Parliament of Australia (2010). The economic environment of the Indian Ocean Territories. Joint Standing Committee on the National Capital and External Territories. https://www.aph.gov.au/Parliamentary Business/Committees/House of Representa tives Committees?url=ncet/economicenvironment/report/chapter\%203.htm

Phosphate Resources Limited (2017). Christmas Island Phosphates Environmental Policy. Environment and community. https://cirp.com.au/environment-community/ourvalues-and-approach/environment-policy/

Pine, B.J., \& Gilmore, J.H. (1999). The experience economy. Harvard Business School.

Ptáček, P. (2016). Apatites and their synthetic analogues. IntechOpen. https://www.intechopen.com/books/apatites-and-their-synthetic-analoguessynthesis-structure-properties-and-applications

Pugh, J. (2018). Relationality and island studies in the Anthropocene. Island Studies Journal, 13(2), 93-110. https://doi.org/10.24043/isj.48

Rainbird, P. (1999). Islands out of time: towards a critique of island archaeology. Journal of Mediterranean Archaeology, 12(2), 216-234. https://doi.org/10.1558/jmea.v12i2.29971

Rice, M. (2017, July 17-19). The 'Anthropocene' misnomer and an alternative: on deobfuscating a discombobulating descriptor [Conference paper]. Annual Conference of the Australian Association for Literature, Griffith University, Gold Coast, Queensland, Australia.

Swarbrick, J.T. (1997). Environmental weeds and exotic plants on Christmas Island, Indian Ocean. Report to Parks Australia. J.T. Swarbrick Weed Science Consultancy.

Trueman, N.A. (1965). The Geology and mineralogy of the phosphate deposits of Christmas Island, Indian Ocean [Unpublished Master's thesis]. University of Adelaide.

UNESCO (2011). Cultural landscapes. https://whc.unesco.org/en/culturallandscape/

UNESCO (2013). Historic quarter of the seaport city of Valparaiso. World Heritage List. https://whc.unesco.org/en/list/959/

Vayda, A.P., \& Rappaport, R.A. (1963). Island cultures. In F.R. Fosberg (Ed.), Man's place in the island ecosystem (pp. 133-144). Bishop Museum Press.

Wilson, E.O. (2010). Island biogeography in the 1960s. In J.B. Losos \& R.E. Ricklefs (Eds.), The theory of island biogeography revisited (pp. 1-12). Princeton University Press. 